\title{
Peramalan Curah Hujan di PPKS Bukit Sentang Dengan Menggunakan Fuzzy Time Series Ruey Chyn Tsaur
}

\author{
Rahmawati Rahmawati, Dyan Elvita Sari, Ade Novia Rahma, Mohammad \\ SOLEH
}

Prodi Matematika, Fakultas Sains dan Teknologi,Universitas Islam Negeri Sultan Syarif Kasim Riau

e-mail: rahmawati@uin-suska.ac.id, dyansr65@gmail.com, adenoviarahma $_{m} u f t i @ y a h o o . c o . i d$, msholeh@uin - suska.ac.id

\begin{abstract}
Abstrak
Perubahan cuaca yang tidak menentu menjadikan cuaca tidak dapat diperkirakan kondisinya di masa yang akan datang. Perubahan cuaca ini juga bergantung pada curah hujan. Pada perkebunan seperti perkebunan kelapa sawit cuaca mempengaruhi banyak aspek salah satunya adalah produktivitas buah kelapa sawit, sehingga untuk waktu ke depan diperlukan peramalan. Peramalan merupakan suatu kegiatan untuk meramalkan apa yang terjadi di masa depan dengan metode tertentu berdasarkan data waktu yang lalu. Metode fuzzy time series dikenal sebagai kecerdasan buatan yang digunakan untuk meramalkan masalah dimana data aktual dibentuk dalam nilai-nilai linguistik menggunakan prinsip fuzzy sebagai dasarnya. Penelitian ini membahas tentang metode fuzzy time series yang dikembangkan oleh Ruey Chyn Tsaur untuk meramalkan curah hujan di PPKS Bukit Sentang, Sumatera Utara. Peramalan curah hujan berdasarkan data Januari 2017 sampai dengan Desember 2020 untuk prediksi tahun 2021. Peramalan ini memiliki nilai MAPE $0,37 \%$ atau memiliki presisi perkiraan 99,63\%. Hasil penelitian menunjukkan bahwa metode Fuzzy Time Series Ruey Chyn Tsaur memiliki tingkat akurasi yang sangat baik untuk meramalkan curah hujan.

Kata kunci: curah hujan, Fuzzy Time Series Ruey Chyn Tsaur, MAPE, peramalan.
\end{abstract}

\begin{abstract}
This weather change also depends on the rainfall. On plantations such as oil palm plantations, the weather affects many aspects, one of which is the productivity of oil palm, so for the future is needed is forecasting. Forecasting is an activity to predict what will happen in the future with certain methods. Fuzzy time series is a method known as artificial intelligence used to predict the problem in which the actual data is formed in linguistic values using fuzzy principles as its basis. This study discusses the method of fuzzy time series developed by Ruey Chyn Tsaur to predict rainfall in PPKS Bukit Sentang, North Sumatera. Forecasting of rainfall based on data from January 2017 to December 2020 to predict in 2021. This study has a 0,37\% of MAPE value or has a 99,63\% of precision forecast. The result shows that the Fuzzy Time Series Ruey Chyn Tsaur method has an excellent level of accuracy for forecasting rainfall.

Keywords: rainfall, Fuzzy Time Series Ruey Chyn Tsaur, MAPE, forecasting.
\end{abstract}

2000 Mathematics Subject Classification: $62 \mathrm{M} 10$

Submitted: 2021-04-13, Revisions: 2021-04-26, Acceptted: 2021-06-28 


\section{Pendahuluan}

Cuaca dipengaruhi dengan beberapa faktor seperti suhu, kelembapan udara, kecepatan angin. Hal ini menunjukkan bahwa banyaknya tuntutan dari berbagai pihak yang membutuhkan informasi tersebut. Kegiatan peramalan merupakan kegiatan yang dilakukan oleh peneliti dalam memperkirakan kejadian di waktu yang akan datang dengan menggunakan pendekatan ilmu tertentu. Beberapa penelitian mengenai kegiatan peramalan berkembang menggunakan beberapa metode dalam menentukan analisis yang paling tepat. Metode fuzzy time series pertama kali diusulkan oleh Song dan Chissom (1993) yang diterapkan dalam konsep logika fuzzy untuk mengembangkan dasar fuzzy time series. Konsep dari fuzzy time series didasarkan pada teori himpunan fuzzy, logika fuzzy dan penalaran perkiraan. Fuzzy time series merupakan proses dinamik dari suatu variabel linguistik yang nilai linguistiknya adalah himpunan fuzzy. Keunggulan pemodelan fuzzy time series adalah mampu memformulasikan suatu permasalahan berdasarkan pengetahuan pakar atau data-data empiris. Penelitian terkait metode fuzzy time series sudah banyak dilakukan oleh peneliti-peneliti sebelumnya diantaranya penelitian oleh Y. Safitri, dkk (2018) mengenai peramalan harga penutupan saham PT. Radiant Utama Interinsco Tbk periode Januari 2011 - Maret 2011 dengan menggunakan metode Fuzzy Time Series Markov Chain. Dari hasil perhitungan didapatkan rata-rata error sebesar $3,48 \%$ [11]. Penelitian kedua dilakukan oleh Yudi (2018) mengenai peramalan penjualan mesin industri rumah tangga metode Fuzzy Time Series Ruey Chyn Tsaur dengan menggunakan 10 kategori dan tipe mesin yang bersumber dari Innovation Household Of Life sebagai bahan keperluan pengujian [13]. Penelitian selanjutnya dilakukan oleh I. Admirani (2020) mengenai prediksi pendaftaran mahasiswa baru model Ruey Chyn Tsaur Fuzzy Time Series. Dari hasil perhitungan didapatkan rata-rata error sebesar $8,48 \%[6]$. Berdasarkan penjelasan dan rujukan penelitian di atas penulis tertarik untuk melakukan penelitian dengan judul Peramalan Curah Hujan di PPKS Bukit Sentang dengan menggunakan Fuzzy Time Series Ruey Chyn Tsaur. .

\section{Metode Penelitian}

Data yang digunakan berdasarkan data klimatologi PPKS Bukit Sentang, Kabupaten Langkat, Sumatera Utara yaitu data curah hujan dari tahun 2017 sampai tahun 2020. Data dianalisis menggunakan metode Fuzzy Time Series Ruey Chyn Tsaur dengan langkah-langkah sebagai berikut :

(1) Memasukkan data curah hujan di PPKS Bukit Sentang yang dijumlah berdasarkan tahun pada 2017 sampai dengan 2020.

(2) Membentuk Himpunan Semesta

Menentukan himpunan semesta dilakukan dengan mencari nilai minimum dan nilai maksimum pada data historis dengan menggunakan persamaan

$$
U=\left[D_{m i n} ; D_{m a k s}\right]
$$

dengan

$D_{\text {min }}=$ nilai minimum pada data, $D_{\text {maks }}=$ nilai maksimum pada data

(3) Membentuk Interval

Membentuk interval dilakukan dengan menghitung banyaknya partisi dengan cara membagi himpunan semesta $(U)$ menjadi beberapa sub interval dan rentang nilai yang sama panjang dengan menggunakan rumus Sturges sebagai berikut:

$$
n=1+3,22 \log N
$$

dengan

$\mathrm{n}=$ banyak partisi, $\mathrm{N}=$ jumlah data historis

Untuk menentukan panjang interval dilakukan dengan menggunakan persamaan sebagai berikut

$$
l=\frac{U_{\max }-U_{\min }}{n}
$$


Kemudian setiap interval diperoleh sebagai berikut

$$
\begin{gathered}
u_{1}=\left[U_{\min } ; U_{\min }+l\right] \\
u_{2}=\left[U_{\min }+l ; U_{\min +2 l}\right] \\
\vdots \\
u_{n}=\left[U_{\min }+(n-1) l ; U_{\min }+n l\right] \\
u_{n}=\left[d_{n} ; d_{n+1}\right]
\end{gathered}
$$

Setelah itu menghitung nilai median

$$
m_{n}=\frac{\left[d_{n}+d_{n+1}\right]}{2}
$$

(4) Menentukan Himpunan Fuzzy

Menentukan himpunan fuzzy untuk semesta pembicaraan $U$. Untuk mempermudah, setiap himpunan fuzzy $A_{i}, i=1,2,3, \ldots, n$ didefinisikan dalam jumlah interval yang telah ditentukan, dimana $A_{1}, A_{2}, \ldots, A_{n}$ didefinisikan berdasarkan persamaan (7) sehingga didapat :

$$
\begin{gathered}
A_{1}=\frac{1}{u_{1}}+\frac{0,5}{u_{2}}+\frac{0}{u_{3}}+\cdots+\frac{0}{u_{i}} \\
A_{2}=\frac{0,5}{u_{1}}+\frac{1}{u_{2}}+\frac{0}{u_{3}}+\cdots+\frac{0}{u_{i}} \\
\vdots \\
A_{1}=\frac{0}{u_{1}}+\frac{0}{u_{2}}+\frac{0}{u_{3}}+\cdots+\frac{0,5}{u_{i-1}}+\frac{0}{u_{i}}
\end{gathered}
$$

(5) Menentukan Fuzzifikasi

Fuzzifikasi ini bertujuan untuk mengubah variabel numerik menjadi variabel fuzzy dengan bentuk interval. Variabel fuzzy dapat diartikan sebagai variabel linguistik. Dalam mengubah variabel numerik ke dalam variabel linguistik dilakukan dengan mengelompokkan data kedalam himpunan samar A yang ditentukan sebelumnya.

(6) Menentukan Fuzzy Logic Relations (FLR)

Fuzzy Logical Relations (FLR) merupakan hubungan antara setiap data dengan data selanjutnya dalam bentuk himpunan dasar $A$. Jika $F(t-1)=A_{i}$ dan $F(t)=A_{j}$ maka hubungan FLR ditulis dengan $A_{i} \rightarrow A_{j}$. Dimana $A_{i}$ sebagai current state atau kejadian saat ini dan $A_{j}$ sebagai next state atau kejadian berikutnya.

(7) Menentukan Fuzzy Logic Relations Group (FLRG)

Logic Relationship Group adalah pengelompokan dari Fuzzy Logic Relationship (FLR). FLRG dibentuk berdasarkan hubungan dengan sisi kiri atau current state yang bersifat tetap.

(8) Menghitung Matriks Probabilitas Transisi

Probabilitas transisi dapat dihitung dengan menggunakan persamaan sebagai berikut:

$$
P_{i j}=\frac{M_{i j}}{M_{i}}, i \text { dan } j=1,2,3, \ldots,
$$

dengan

$P_{i j}=$ probabilitas transisi dari kejadian $i$ dan $j$

$M_{i j}=$ jumlah transisi dari $i$ dan $j, M_{i}=$ jumlah kejadian yang terjadi $i$ dan $j$

Matriks probabilitas transisi ditulis sebagai berikut :

$$
\left[P_{i j}\right]_{n \times n}=\left(\begin{array}{ccc}
P_{11} & \ldots & P_{1 n} \\
\ldots & P_{22} & \ldots \\
P_{n 1} & \ldots & P_{n n}
\end{array}\right)
$$

dengan $P_{i j} \geq 0$ dan $\sum_{j=0}^{\infty} P_{i j}=1$

(9) Menentukan Defuzzifikasi

(a) Menghitung Peramalan Awal

Dihasilkan berdasarkan FLR, FLRG dan matriks probabilitas transisi yang telah diperoleh sebelumnya. Peramalan awal $(F(t))$ dengan $t=1,2,3, \ldots, n$ dapat menggunakan cara sebagai berikut 
(i) Jika FLRG dari $A_{i}$ merupakan himpunan kosong $\left(A_{i} \rightarrow \emptyset\right)$ maka peramalan adalah $m_{i}$ yaitu titik tengah dari $u_{i}$ dengan persamaan :

$$
F(t)=m_{i}
$$

(ii) Jika FLRG dari $A_{i}$ merupakan himpunan one to one $\left(A_{i} \rightarrow A_{k}\right)$ dimana $P_{i j}=0$ dan $P_{i k}=1, j \neq k$ maka hasil peramalan $f(t)$ adalah $m_{k}$ yaitu nilai tengah dari $u_{k}$ dengan persamaan:

$$
F(t)=m_{k} P_{j k}=m_{k}
$$

(iii) Jika FLRG merupakan himpunan one to many $\left(A_{i} \rightarrow A_{1}, A_{2}, A_{3}, \ldots, A_{j}\right)$ dengan $Y_{t-1}$ adalah sebenarnya $(t-1)$ maka hasil peramalan dilakukan dengan menggunakan persamaan berikut :

$$
F(t)=m_{1} P_{i 1}+m_{2} P_{i 2}+\cdots+m_{i-1} P_{i(i-1)}+Y_{(t-1)} P_{i i}+m_{i+1} P_{i(i+1)}+\cdots+m_{i} P_{i}
$$

(b) Menyesuaikan Kecenderungan Nilai Peramalan

(i) Jika FLR $A_{i}$ berkomunikasi dengan $A_{j}$, dimulai dari state $A_{i}$ saat waktu $t-1$ sebagai $F(t-1)=A_{i}$ dan membuat transisi naik ke state $A_{j}$ pada waktu $t$, dimana $(i<j)$

$$
D=\frac{l \times s}{2}
$$

dengan

$l=$ panjang interval, $s=$ banyaknya transisi maju

(ii) Jika FLR $A_{i}$ berkomunikasi dengan $A_{j}$ dimulai dari state $A_{i}$ saat waktu $t-1$ sebagai $F(t-1)=A_{i}$ dan membuat transisi mundur ke state $A_{j}$ pada waktu $t$ dimana $(i>j)$

$$
D=-\left(\frac{l \times r}{2}\right)
$$

dengan

$l=$ panjang interval, $r=$ banyaknya transisi mundur

(iii) Jika FLR $A_{i}$ berkomunikasi dengan dengan $A_{j}$ dimana $i=j$ maka nilai kecenderungan hasil dari peramalan yaitu $D=0$.

(c) Menghitung Hasil Peramalan Akhir

Peramalan hasil akhir didapatkan dari proses penggabungan fuzzy time series dan markov chain dilakukan dengan perhitungan dengan menggunakan persamaan sebagai berikut

$$
F^{\prime}(t)=F(t)+D
$$

dengan

$F^{\prime}(t)=$ hasil peramalan akhir, $F(t)=$ hasil peramalan awal

$D=$ nilai kecenderungan peramalan

(10) Menghitung Mean Absolute Percentage Error (MAPE)

MAPE adalah ketepatan relatif yang digunakan mengetahui presentase penyimpangan dari hasil peramalan.

$$
M A P E=\frac{1}{n} \sum_{t=1}^{n} \frac{\left|Y(t)-F^{\prime}(t)\right|}{Y(t)} \times 100
$$

dengan

MAPE $=$ nilai Mean Absolute Percentage Error, $n=$ jumlah data curah hujan $Y(t)=$ data aktual pada waktu $t, F^{\prime}(t)=$ nilai hasil peramalan pada waktu $t$

(11) Peramalan Periode Berikutnya

Tahap ini dapat dilakukan apabila model peramalan dengan menggunakan fuzzy time series ruey chyn tsaur mendapatkan kriteria baik. 


\section{Hasil Dan Pembahasan}

Penelitian ini menggunakan data curah hujan di PPKS Bukit Sentang mulai Januari 2017 sampai dengan Desember 2020 yang disajikan dalam Tabel 1. Data ini diolah dengan menggunakan Logika Ruey Chyn Tsaur.

TABEL 1. Data curah hujan tahun 2017-2020

\begin{tabular}{|c|c|c|c|c|}
\hline \multirow{2}{*}{ Bulan } & \multicolumn{4}{|c|}{ Tahun $(\mathrm{mm})$} \\
\cline { 2 - 5 } & 2017 & 2018 & 2019 & 2020 \\
\hline Januari & 189 & 144 & 128 & 45 \\
\hline Februari & 90 & 97 & 73 & 121 \\
\hline Maret & 95 & 101 & 59 & 28 \\
\hline April & 303 & 128 & 82 & 137 \\
\hline Mei & 163 & 63 & 205 & 316 \\
\hline Juni & 223 & 126 & 310 & 231 \\
\hline Juli & 142 & 79 & 60 & 77 \\
\hline Agustus & 299 & 152 & 98 & 185 \\
\hline September & 257 & 319 & 152 & 377 \\
\hline Oktober & 215 & 303 & 182 & 347 \\
\hline November & 321 & 110 & 187 & 327 \\
\hline Desember & 265 & 174 & 139 & 397 \\
\hline
\end{tabular}

\section{Penerapan Logika Ruey Chyn Tsaur}

(1) Menentukan himpunan semesta

Berdasarkan data Tabel 1 didapatkan himpunan semesta :

$$
U=\left[D_{\min } ; D_{\text {maks }}\right]=[28 ; 397]
$$

(2) Menentukan interval

Pembagian himpunan semesta $U$ menjadi beberapa partisi dari interval $(n)$ menggunakan rumus Sturges pada Persamaan (2)

$$
n=1+3,222 \log N=1+3,222 \log (48)=6,41 \approx 6
$$

Setiap partisi memiliki panjang interval yang sama, dapat dicari dengan menggunakan Persamaan (3).

$$
l=\frac{U_{m a k s}-U_{\min }}{n}=\frac{397-28}{6}=\frac{369}{6}=61,5
$$

Setelah itu, dicari definisi partisi $u_{1}, u_{2}, u_{3}, u_{4}, u_{5}, u_{6}$ dari himpunan semesta $U$

$$
\begin{gathered}
u_{1}=[29 ; 89,5], u_{2}=[89,5 ; 151], u_{3}=[151 ; 212,5] \\
u_{4}=[212,5 ; 274], u_{5}=[274 ; 335,5], u_{6}=[335,5 ; 397]
\end{gathered}
$$

Kemudian dilakukan perhitungan nilai tengah $(m)$ dari setiap himpunan semesta $U$

$$
m_{1}=58,75 ; m_{2}=120,25 ; m_{3}=181,75 ; m_{4}=243,25 ; m_{5}=304,75 ; m_{6} 366,25
$$


(3) Menentukan himpunan fuzzy

Menentukan himpunan fuzzy atau fuzzy set Adilakukan Persamaan (6) sebagai berikut

$$
\begin{aligned}
& A_{1}=\frac{1}{u_{1}}+\frac{0,5}{u_{2}}+\frac{0}{u_{3}}+\frac{0}{u_{4}}+\frac{0}{u_{5}}+\frac{0}{u_{6}} \\
& A_{2}=\frac{0,5}{u_{1}}+\frac{1}{u_{2}}+\frac{0,5}{u_{3}}+\frac{0}{u_{4}}+\frac{0}{u_{5}}+\frac{0}{u_{6}} \\
& A_{3}=\frac{0}{u_{1}}+\frac{0,5}{u_{2}}+\frac{1}{u_{3}}+\frac{0,5}{u_{4}}+\frac{0}{u_{5}}+\frac{0}{u_{6}} \\
& A_{4}=\frac{0}{u_{1}}+\frac{0}{u_{2}}+\frac{0,5}{u_{3}}+\frac{1}{u_{4}}+\frac{0,5}{u_{5}}+\frac{0}{u_{6}} \\
& A_{5}=\frac{0}{u_{1}}+\frac{0}{u_{2}}+\frac{0}{u_{3}}+\frac{0,5}{u_{4}}+\frac{1}{u_{5}}+\frac{0,5}{u_{6}} \\
& A_{6}=\frac{0}{u_{1}}+\frac{0}{u_{2}}+\frac{0}{u_{3}}+\frac{0}{u_{4}}+\frac{0,5}{u_{5}}+\frac{1}{u_{6}}
\end{aligned}
$$

(4) Fuzzifikasi

Tahap fuzzifikasi ditentukan berdasarkan pada nilai linguistik berdasarkan himpunan fuzzy yang telah ditentukan sebelumnya. Berikut diberikan data fuzzyfikasi dari data diatas yang disajikan pada Tabel 2 berikut.

TABEL 2. Data Fuzzyfikasi

\begin{tabular}{|c|c|c|c|}
\hline No & Periode & Numerik $(\mathrm{mm})$ & Fuzzifikasi \\
\hline 1 & Januari 2017 & 189 & $A_{3}$ \\
\hline 2 & Februari 2017 & 90 & $A_{2}$ \\
\hline 3 & Maret 2017 & 95 & $A_{2}$ \\
\hline 4 & April 2017 & 303 & $A_{5}$ \\
\hline 5 & Mei 2017 & 163 & $A_{3}$ \\
\hline 6 & Juni 2017 & 223 & $A_{4}$ \\
\hline 7 & Juli 2017 & 142 & $A_{2}$ \\
\hline$\vdots$ & $\vdots$ & $\vdots$ & $\vdots$ \\
\hline 44 & Agustus 2020 & 185 & $A_{3}$ \\
\hline 45 & September 2020 & 377 & $A_{6}$ \\
\hline 46 & Oktober 2020 & 347 & $A_{6}$ \\
\hline 47 & November 2020 & 327 & $A_{5}$ \\
\hline 48 & Desember 2020 & 397 & $A_{6}$ \\
\hline
\end{tabular}

(5) Menentukan Fuzzy Logic Relations (FLR)

Fuzzy Logical Relationship (FLR) dicari dengan menggunakan data fuzzyfikasi. Data Fuzzy Logic Relations (FLR) disajikan pada Tabel 3 berikut. 
TABel 3. Data FLR

\begin{tabular}{|c|c|c|c|}
\hline No & Periode & Numerik $(\mathrm{mm})$ & FLR \\
\hline 1 & Januari 2017 & 189 & - \\
\hline 2 & Februari 2017 & 90 & $A_{3} \rightarrow A_{2}$ \\
\hline 3 & Maret 2017 & 95 & $A_{2} \rightarrow A_{2}$ \\
\hline 4 & April 2017 & 303 & $A_{2} \rightarrow A_{5}$ \\
\hline 5 & Mei 2017 & 163 & $A_{5} \rightarrow A_{3}$ \\
\hline 6 & Juni 2017 & 223 & $A_{3} \rightarrow A_{4}$ \\
\hline 7 & Juli 2017 & 142 & $A_{4} \rightarrow A_{2}$ \\
\hline$\vdots$ & $\vdots$ & $\vdots$ & $\vdots$ \\
\hline 44 & Agustus 2020 & 185 & $A_{1} \rightarrow A_{3}$ \\
\hline 45 & September 2020 & 377 & $A_{3} \rightarrow A_{6}$ \\
\hline 46 & Oktober 2020 & 347 & $A_{6} \rightarrow A_{6}$ \\
\hline 47 & November 2020 & 327 & $A_{6} \rightarrow A_{5}$ \\
\hline 48 & Desember 2020 & 397 & $A_{5} \rightarrow A_{6}$ \\
\hline
\end{tabular}

(6) Menentukan Fuzzy Logic Relations Grup (FLRG)

Nilai Fuzzy Logic Relations Grup (FLRG) ditentukan berdasarkan hubungan current state ke next state yang kemudian dikelompokkan, dimana current state atau kejadian saat ini bersifat tetap. Pada Tabel 4 berikut disajikan data FLRG.

TABEL 4. Hasil FLRG

\begin{tabular}{|c|c|c|}
\hline Current State & Next Stage & FLRG \\
\hline$A_{1}$ & $2 A_{1}, 4 A_{2}, 3 A_{3}$ & $A_{1} \rightarrow 2 A_{1}, 4 A_{2}, 3 A_{3}$ \\
\hline$A_{2}$ & $5 A_{1}, 4 A_{2}, 2 A_{3}, 3 A_{5}$ & $A_{2} \rightarrow 5 A_{1}, 4 A_{2}, 2 A_{3}, 3 A_{5}$ \\
\hline$A_{3}$ & $3 A_{2}, 2 A_{3}, 1 A_{4}, 2 A_{5}, 1 A_{6}$ & $A_{3} \rightarrow 3 A_{2}, 2 A_{3}, 1 A_{4}, 2 A_{5}, 1 A_{6}$ \\
\hline$A_{4}$ & $1 A_{1}, 2 A_{2}, 1 A_{5}$ & $A_{4} \rightarrow 1 A_{1}, 2 A_{2}, 1 A_{5}$ \\
\hline$A_{5}$ & $1 A_{1}, 1 A_{2}, 1 A_{3}, 3 A_{4}, 2 A_{5}, 1 A_{6}$ & $A_{5} \rightarrow 1 A_{1}, 1 A_{2}, 1 A_{3}, 3 A_{4}, 2 A_{5}, 1 A_{6}$ \\
\hline$A_{6}$ & $1 A_{5}, 1 A_{6}$ & $A_{6} \rightarrow 1 A_{5}, 1 A_{6}$ \\
\hline
\end{tabular}

(7) Menghitung Matriks Probabilitas Transisi

Matriks Probabilitas transisi ditentukan berdasarkan dari data fuzzifikasi sampai dengan FLRG pada tiap data. Matriks probabilitas transisi pada data berorde $6 \times 6$ berdasarkan interval sebelumnya.

$$
P=\left[\begin{array}{cccccc}
2 / 9 & 4 / 9 & 3 / 9 & 0 & 0 & 0 \\
5 / 14 & 4 / 14 & 2 / 14 & 0 & 3 / 14 & 0 \\
0 & 3 / 9 & 2 / 9 & 1 / 9 & 2 / 9 & 1 / 9 \\
1 / 4 & 2 / 4 & 0 & 0 & 1 / 4 & 0 \\
1 / 9 & 1 / 9 & 1 / 9 & 3 / 9 & 2 / 9 & 1 / 9 \\
0 & 0 & 0 & 0 & 1 / 2 & 1 / 2
\end{array}\right]
$$

(8) Defuzzifikasi

Peramalan awal dapat dilihat pada matriks probabilitas transisi berdasarkan nilai probabilitas, kemudian dapat dilakukan perhitungan untuk peramalan berdasarkan data histori. 
TABel 5. Hasil Data Peramalan Awal

\begin{tabular}{|c|c|c|c|}
\hline No & Periode & Data Aktual $(\mathrm{mm})$ & Peramalan Awal $F(t)(\mathrm{mm})$ \\
\hline 1 & Januari 2017 & 189 & - \\
\hline 2 & Februari 2017 & 90 & 215 \\
\hline 3 & Maret 2017 & 95 & 136 \\
\hline 4 & April 2017 & 303 & 137 \\
\hline 5 & Mei 2017 & 163 & 227 \\
\hline 6 & Juni 2017 & 223 & 210 \\
\hline 7 & Juli 2017 & 142 & 151 \\
\hline$\vdots$ & $\vdots$ & $\vdots$ & $\vdots$ \\
\hline 44 & Agustus 2020 & 185 & 130 \\
\hline 45 & September 2020 & 377 & 341 \\
\hline 46 & Oktober 2020 & 347 & 326 \\
\hline 47 & November 2020 & 327 & 232 \\
\hline 48 & Desember 2020 & 397 & \\
\hline
\end{tabular}

Pada tahap ini dilakukan untuk menyelesaikan kecenderungan nilai dari peramalan dengan menggunakan Persamaan (12) sampai dengan Persamaan (13).

TABel 6. Hasil Data Kecenderungan Peramalan

\begin{tabular}{|c|c|c|c|}
\hline No & Periode & FLR & D \\
\hline 1 & Januari 2017 & - & - \\
\hline 2 & Februari 2017 & $A_{3} \rightarrow A_{2}$ & $-92,25$ \\
\hline 3 & Maret 2017 & $A_{2} \rightarrow A_{2}$ & 0 \\
\hline 4 & April 2017 & $A_{2} \rightarrow A_{5}$ & 92,25 \\
\hline 5 & Mei 2017 & $A_{5} \rightarrow A_{3}$ & $-30,75$ \\
\hline 6 & Juni 2017 & $A_{3} \rightarrow A_{4}$ & 30,75 \\
\hline 7 & Juli 2017 & $A_{4} \rightarrow A_{2}$ & $-61,5$ \\
\hline$\vdots$ & $\vdots$ & $\vdots$ & $\vdots$ \\
\hline 44 & Agustus 2020 & $A_{1} \rightarrow A_{3}$ & 92,25 \\
\hline 45 & September 2020 & $A_{3} \rightarrow A_{6}$ & 30,75 \\
\hline 46 & Oktober 2020 & $A_{6} \rightarrow A_{6}$ & 0 \\
\hline 47 & November 2020 & $A_{6} \rightarrow A_{5}$ & $-30,75$ \\
\hline 48 & Desember 2020 & $A_{5} \rightarrow A_{6}$ & 30,75 \\
\hline
\end{tabular}

Pada tahap menentukan hasil peramalan akhir, digunakan Persamaan (14) yang didapat dari tahap peramalan awal dan penyesuaian hasil peramalan. 
TABel 7. Hasil Data Peramalan Akhir

\begin{tabular}{|c|c|c|c|c|c|}
\hline No & Periode & Peramalan Akhir $F^{\prime}(t)(\mathrm{mm})$ & No & Periode & Peramalan Akhir $F^{\prime}(t)(\mathrm{mm})$ \\
\hline 1 & Januari 2017 & - & 25 & Januari 2019 & 119,75 \\
\hline 2 & Februari 2017 & 122,75 & 26 & Februari 2019 & $-7,75$ \\
\hline 3 & Maret 2017 & 136 & 27 & Maret 2019 & 129 \\
\hline 4 & April 2017 & 229,25 & 28 & April 2019 & 126 \\
\hline 5 & Mei 2017 & 196,25 & 29 & Mei 2019 & 223,25 \\
\hline 6 & Juni 2017 & 240,75 & 30 & Juni 2019 & 280,5 \\
\hline 7 & Juli 2017 & 89,5 & 31 & Juli 2019 & 197,25 \\
\hline 8 & Agustus 2017 & 242,25 & 32 & Agustus 2019 & 249 \\
\hline 9 & September 2017 & 133,75 & 33 & September 2019 & 199,5 \\
\hline 10 & Oktober 2017 & 262,75 & 34 & Oktober 2019 & 207 \\
\hline 11 & November 2017 & 207 & 35 & November 2019 & 214 \\
\hline 12 & Desember 2017 & 138,75 & 36 & Desember 2019 & 122,75 \\
\hline 13 & Januari 2018 & 89,5 & 37 & Januari 2020 & $-4,75$ \\
\hline 14 & Februari 2018 & 151 & 38 & Februari 2020 & 246 \\
\hline 15 & Maret 2018 & 138 & 39 & Maret 2020 & $-9,75$ \\
\hline 16 & April 2018 & 139 & 40 & April 2020 & 242 \\
\hline 17 & Mei 2018 & $-7,75$ & 41 & Mei 2020 & 241,25 \\
\hline 18 & Juni 2018 & 250 & 42 & Juni 2020 & 137,75 \\
\hline 19 & Juli 2018 & $-7,75$ & 43 & Juli 2020 & 120,25 \\
\hline 20 & Agustus 2018 & 222,25 & 44 & Agustus 2020 & 222,25 \\
\hline 21 & September 2018 & 268,5 & 45 & September 2020 & 244,75 \\
\hline 22 & Oktober 2018 & 230 & 46 & Oktober 2020 & 341 \\
\hline 23 & November 2018 & 196,25 & 47 & November 2020 & 295,25 \\
\hline 24 & Desemebr 2018 & 202,5 & 48 & Desember 2020 & 351 \\
\hline
\end{tabular}

Data aktual tahun 2017-2020 dan data peramalan curah hujan di PPKS Bukit Sentang pada tahun 2021 dari data diatas dapat disajikan dalam bentuk grafik seperti pada Gambar 1 berikut.

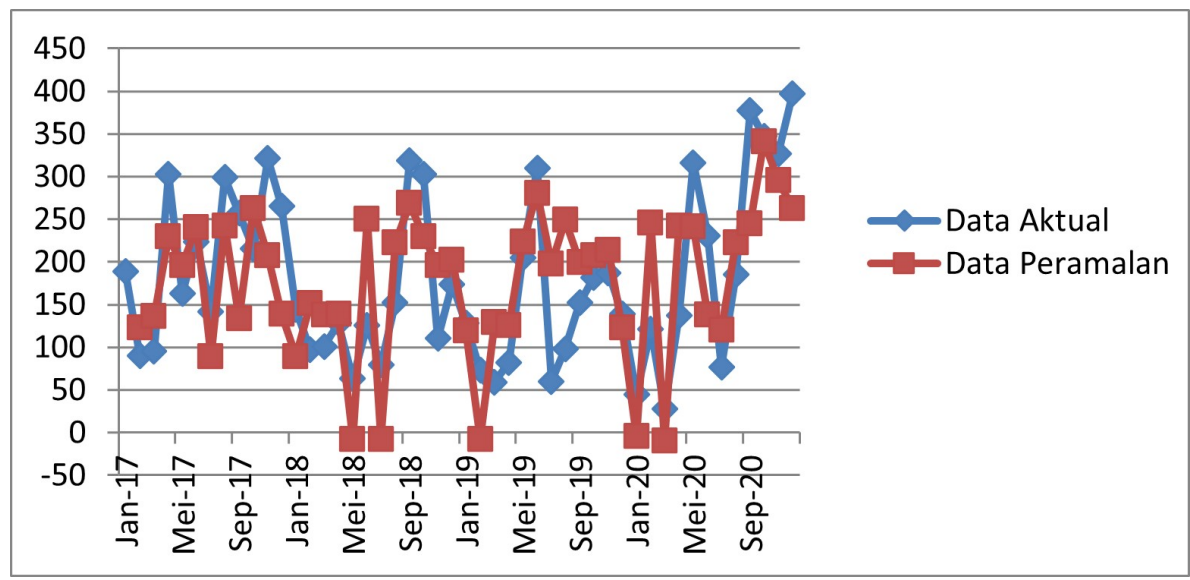

GAmbar 1. Data aktual dan data peramalan curah hujan tahun 2017-2020

Berdasarkan perhitungan dengan menggunakan Persamaan (15) didapatkan ratarata MAPE sebesar 0,05\%. Nilai rata-rata error dihasilkan antara $<10 \%$, maka hasilnya dianggap sangat baik, artinya pengujian curah hujan di PPKS Bukit Sentang 
ini dapat diterima. Setelah didapatkan model logika Ruey Chyn Tsaur seperti yang telah di bahas diatas, kemudian dilakukan peramalan curah hujan di PPKS Bukit Sentang, peramalan dilakukan pada 1 tahun berikutnya yaitu Januari 2021-Desember 2021. Hasil dari peramalan dilihat pada Tabel 8 berikut ini:

TABel 8. Hasil Data Peramalan Januari 2021-Desember 2021

\begin{tabular}{|c|c|c|c|c|c|}
\hline No & Periode & Peramalan Awal (mm) & Penyesuaian & Peramalan Akhir (mm) & Error \\
\hline 1 & Januari 2021 & 351 & 0 & 351 & $0,51 \%$ \\
\hline 2 & Februari 2021 & 151 & 0 & 151 & $0,57 \%$ \\
\hline 3 & Maret 2021 & 328 & 0 & 328 & $1,17 \%$ \\
\hline 4 & April 2021 & 207 & $-61,5$ & 146 & $0,55 \%$ \\
\hline 5 & Mei 2021 & 232 & 30,75 & 263 & $0,8 \%$ \\
\hline 6 & Juni 2021 & 151 & 0 & 151 & $0,43 \%$ \\
\hline 7 & Juli 2021 & 151 & 0 & 151 & $0,01 \%$ \\
\hline 8 & Agustus 2021 & 207 & 0 & 207 & $0,37 \%$ \\
\hline 9 & September 2021 & 207 & 0 & 207 & $0 \%$ \\
\hline 10 & Oktober 2021 & 219 & 0 & 219 & $0,06 \%$ \\
\hline 11 & November 2021 & 219 & 30,75 & 250 & $0 \%$ \\
\hline 12 & Desember 2021 & 151 & 0 & 151 & $0 \%$ \\
\hline
\end{tabular}

\section{Kesimpulan DAN SARAN}

Berdasarkan uraian yang telah dibahas, dapat disimpulkan bahwa hasil peramalan menggunakan logika Ruey Chyn Tsaur didapatkan hasil MAPE sebesar 0,05\%. Karena hasil MAPE yang didapatkan $<10 \%$, maka peramalan ini masuk ke dalam kriteria sangat baik. Hasil peramalan curah hujan di PPKS Bukit Sentang menggunakan logika Ruey Chyn Tsaur untuk bulan Januari 2021 sebesar $351 \mathrm{~mm}$ sampai dengan Desember 2021 sebesar $151 \mathrm{~mm}$ dengan hasil rata rata MAPE 0,37\% yang masuk ke dalam kategori sangat baik. Setelah membahas dan mengimplementasikan logika Ruey Chyn Tsaur ini, untuk penelitian selanjutnya dapat dilakukan perbandingan hasil dengan metode time series lain yang mungkin saja bias mendapatkan error yang lebih kecil.

\section{DAFtar Pustaka}

[1] Aliek B.R.D.P., 2018, Penerapan Model FTS-Markov Chain untuk Peramalan Cuaca di Jalur Penyebrngan Gresik Bawean, Skripsi Sarjana Fakultas Sains dan Teknologi Universitas Islam Negeri Sunan Ampel Surabaya.

[2] Tjasyono B., 1999, Klimatologi Umum.Penerbit ITB.Bandung.

[3] Churrohmah, Mifta, 2020, Peramalan Penjualan Mobil di Indonesia menggunakan Data Runtun Waktu dengan Logika Ruey Chyn Tsaur, Skripsi Sarjana Fakultas Sains dan Teknologi Universitas Islam Negeri Sunan Ampel Surabaya.

[4] Faroh, Rifky Aisyatul, Penerapan Model Fuzzy Time Series-Markov Chain untuk Peramalan Inflasi, Skripsi Sarjana Fakultas Sains dan Teknologi Universitas Islam Negeri Maulana Malik Ibrahim Malang.

[5] Riyadli H., Arliyana, 2018, Analisis Tingkat Akurasi Algoritma Novel Sebagai Metode Prediksi(Studi Kasus : Prediksi Harga Emas), STMIK Palangka Raya.

[6] Admirani I., 2020, Model Ruey Chyn Tsaur Time Series Untuk Prediksi Pendaftran Mahasiswa Baru, Jurnal JUPITER, Vol.12, No.2.

[7] Makridakis, 1999, Metode Aplikasi dan Permalan.Edisi 2, Jakarta:Binarupa Aksara

[8] Vaoziah S., 2016, Peramalan Indeks Saham Syariah Dengan Metode Fuzzy Time Series Ruey Chyn Tsaur, Skripsi Fakultas Sains dan Teknologi UIN Sunan Kalijaga Yogyakarta.

[9] Tsaur R.C., 2012, A Fuzzy Time Series-Markov Chain Model With An application To Forecast The Exchange Rate Beetween The Taiwan And US Dollar, International Journal Of Innovative Computing, Information and Control.4391-4992. 
[10] Anggraini Y.D., 2018, Analisis Data Runtun Waktu Untuk peramlan Penjualan Sepeda Motor di Indonesia Menggunakan Metode Fuzzy Time Series dengan Logika Cheng dan Logika Ruey Chyn Tsaur, Tugas Akhir Fakultas Matematika dan Ilmu Pengetahuan Universitas Islam Indonesia.

[11] Safitri S., Wahyuningsih S.,and Goejantoro R., 2018, Peramalan dengan Metode Fuzzy Time Series Markov Chain (Studi Kasus : Harga Penutupan Saham PT. Radiant Utama Interinsco Tbk Periode Januari 2011 Maret 2011), Jurnal EKSPONENSIAL, Vol.9, No.1, Pages 51-58.

[12] Yehoshua, Kustanto and Vulandari R.T, 2020, Prediksi Penjualan Produk Promo PT.Unilever tbk Menggunakan Metode Fuzzy Time Series, Jurnal INFORMA Politeknik Indonusa Surakarta, Vol.6, No.2.

[13] Yudi, 2018, Peramalan Penjualan Mesin Industri Rumah Tangga Dengan Metode Fuzzy Time Series Ruey Chyn Tsaur, Jurnal Informatika Kaputama, Vol.2, No.1. 